Ks. Marek STAROWIEYSKI

(Warszawa, PWTW, UW)

\title{
PLUSKWY POSŁUSZNE ŚW. JANOWI APOSTOŁOWI (Dzieje Jana 62)
}

W apokryficznych Dziejach Jana Apostoła znajduje się krótki epizod o Apostole wypędzającym w gospodzie pluskwy. Epizod ten był przedmiotem zainteresowania współczesnych uczonych; temu to właśnie epizodowi poświęcony jest i niniejszy artykuł.

Apokryficzne Dzieje Jana należą do grupy pięciu najstarszych apokryficznych Dziejów Apostołów, które powstawały w języku greckim w okresie 2. poł. II i 1. poł. III wieku1. Są to Dzieje Piotra, Dzieje Pawła, Dzieje Andrzeja, Dzieje Tomasza i Dzieje Jana. Wszystkie te utwory zachowały się w mniejszych czy większych fragmentach, z wyjątkiem Dziejów Tomasza, które przetrwały w dwóch całościowych wersjach: greckiej i syryjskiej, pochodzących od wspólnego tekstu greckiego. Dzieje te stanowią same dla siebie gatunek literacki, choć są spokrewnione zarówno $\mathrm{z}$ gatunkami popularnymi w starożytności, a więc np. z romansem starożytnym czy z anegdotą filozoficzną.

Jednym z bardzo ważnych elementów tych najstarszych opowiadań o Apostołach są różnorodne opowiadania o zwierzętach, które w nich odgrywają niemałą rolę; podobnie zresztą pojawiają się one w apokryfach późniejszych. Te zazwyczaj kilkustronicowe teksty służą do wykazania w sposób niezwykły i bardzo plastyczny, jak realizuje się plan Boży przez Apostoła, i stanowią przykłady dla katechezy wykazującej nadzwyczajną moc Boga działającego przez Apostoła, dzięki której poganie się nawracają; spełniają więc rolę zarówno teologiczną, jak i apologetyczną².

Dzieje Jana pochodzą z 2. poł. II wieku. Ich autorem jest chrześcijanin nawrócony z pogaństwa i są przeznaczone dla świata pogańskiego. Powstały prawdopodobnie w środowisku małoazjatyckim, w kręgach ortodoksyjnych,

${ }^{1}$ O apokryficznych dziejach Apostołów, por. Apokryfy Nowego Testamentu, red. M. Starowieyski, II/1: Apostołowie, Kraków 2007; Dzieje Jana i literatura o nich, tamże, s. 284-408.

${ }^{2}$ Zestaw ich podaje M. Söder, Die apokryphen Apostelgeschichten und die romanhafte Literatur der Antike, Stuttgart 1969, 60-64, 110n. Podajmy kilka przykładów: pies spełnia ważną rolę w walce Piotra z Szymonem Magiem (DzP 9-12), lwica broni Tekli (DzPw 8), osiołek bierze Tomasza na swój grzbiet i wiezie do miasta (DzTm 39-41), leopard z koziołkiem stają się uczniami Filipa (DzFlp 96-101), itd. 
choć później włączono do nich partie gnostyckie, jak np. sławny hymn tańczącego Chrystusa.

Opowiadanie o pluskwach, którym się teraz zajmiemy, jest typową anegdotą filozoficzną, a przez swój morał końcowy jest zbliżona do bajek o zwierzętach. Jest to opowiadanie stosunkowo krótkie, opowiedziane w pierwszej osobie, a więc sprawiające wrażenie opowiadania naocznego świadka. Takie opowiadanie stanowi dość rzadki wypadek w apokryfach. Ponadto nie ma ono żadnego wydźwięku teologicznego - zawiera tylko końcowy morał: porównanie odpowiedzi pluskiew na słowo ludzkie i nieczułości ludzi na słowo Boże.

Dzieje Jana, jak i inne apokryficzne Dzieje, składają się z epizodów. Historia o pchłach znajduje się w ich epizodzie dziesiątym, którego treścią jest powtórny pobyt Apostoła w Efezie. Wydarzenie to miało mieć miejsce w drodze Apostoła do Efezu. Jeśli chodzi o miejsce opowiadania o pluskwach w Dziejach Jana, to ten żart Jana stanowi pogodny przerywnik przed ponurą historią Druzjany i Kallimacha. Z punktu widzenia kompozycji dzieła, fragment ten jest dość luźno związany z tokiem opowiadania.

\section{Opowiadanie o pluskwach w gospodzie ${ }^{3}$.}

62(60). Pierwszego dnia, zatrzymaliśmy się w pewnej gospodzie na pustkowiu. Gdy szukaliśmy łóżka, aby błogosławiony Jan mógł odpocząć, ujrzeliśmy jeden z jego żartów (gr. $\pi \alpha i ́ \gamma v ı$ rov). Znajdowało się gdzieś tam łóżko bez nakrycia. Rozciągnęliśmy więc płaszcze, które mieliśmy z sobą i poprosiliśmy go, aby odpoczął położywszy się. Inni położyli się spać na podłodze. Ale skoro tylko on się położył, zaczęło go napastować mnóstwo pluskiew. A gdy one coraz bardziej mu dokuczały, a upłynęło już pół nocy, rzekł do nich, a usłyszeliśmy to wszyscy: «Mówię wam, pluskwy, okażcie się życzliwe wszystkie razem, opuśćcie w tej chwili wasz dom, siedźcie spokojnie

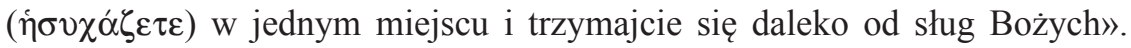
A gdy my zaczęliśmy się śmiać i rozmawialiśmy coraz głośniej, Jan usnął. My zaś rozmawialiśmy cicho, staraliśmy się bowiem mu nie przeszkadzać.

63(61). Wstałem, gdy zaczęło świtać, a wraz ze mną Werus i Andronikus, i oto ujrzeliśmy przy drzwiach ogromny thum pluskiew. Na widok tego thumu stanęliśmy pełni zdumienia, a wszyscy bracia obudzili się z ich powodu. Jan zaś dalej spał. Po przebudzeniu opowiedzieliśmy to, co widzieliśmy. On zaś, powstawszy z łóżka, spojrzał na nie i rzekł do pluskiew: «Ponieważ byłyście życzliwe i zachowałyście moje ostrzeżenie, wróćcie na swoje miejsce». Gdy on to powiedział i wstał z łóżka, pluskwy rozbiegły się od drzwi, śpieszyły ku

${ }^{3}$ Por. Acta Joannis, ed. E. Junod - J.D. Kaestli, CCAp 1, Turnhout 1983, ss. VII-XXI (Bibliographie), 1-158 (Introduction), 169-315 (Texte et traduction francaise), 319-419 (Textes annexes), tłum. M. Starowieyski, w : Apokryfy Nowego Testamentu, II/1, Kraków 2007, 285-294 (Wstęp), 294-408 (przekład). 
łóżku, i drapiąc się po jego nogach zniknęły w jego złączeniach. Wtedy Jan znowu powiedział: «Te zwierzęta, skoro usłyszały głos człowieka, pozostały na swoim miejscu ( wo Boże, ale przestępujemy Jego przykazania i lekceważymy je. Ale aż do kiedy?»". ${ }^{4}$

2. Opowiadania o zwierzętach i pluskwach w starożytności. Określmy najpierw, o jakie zwierzęta chodzi w tym opowiadaniu? W rękopisach wystę-

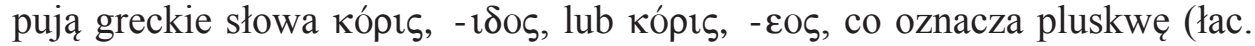
cimex); obydwa słowa występują zamiennie w rękopisach naszego fragmentu, ale obok nich pojawia się także w tym miejscu słowo: кópoı - dziewczęta; dając tekstowi posmak erotyczno-komiczny, tym bardziej, że to Apostoł z łóżka

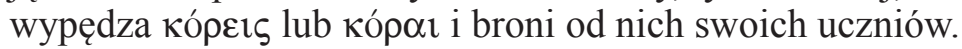

Nasze opowiadanie wpisuje się do grupy antycznych opowiadań o zwierzętach, w których jednak rzadko występują pluskwy, robaki podłe i pogardzane (animal foedissimum) ${ }^{5}$, o których jest mowa zawsze w kontekście negatywnym. Jak więc są one przedstawiane w literaturze antycznej6? Odpowiedź na to pytanie pozwoli lepiej zrozumieć omawiany fragment Dziejów Jana. Podane niżej omówienie pozwoli głębiej zrozumieć nasze opowiadanie w szerszym kontekście.

Omówienie pluskiew znajdujemy w dziełach mówiących szerzej o zwierzętach, a więc w Zoologii Arystotelesa ${ }^{7}$, a także u Warrona ${ }^{8}$ i Pliniusza ${ }^{9}$, a później w wielkiej średniowiecznej encyklopedii łacińskiej Izydora z Sewilli ${ }^{10}$. Pojawia się ono także w licznych dziełach o rolnictwie i gospodarstwie, których tu nie będziemy omawiać ${ }^{11}$.

Pluskwy stanowiły plagę zajazdów i innych publicznych lokali, nie dając ludziom spać lub budząc ich ze snu. Pluskwy kilkakrotnie wspominane są w komediach Arystofanesa. W jego Chmurach mamy żale Strepsjadesa, poże-

${ }^{4}$ Acta Joannis 62 (60) - 63 (61), CCAp 1, 247-251, thum. (poprawione) Apokryfy Nowego Testamentu, II/1, 320. Opracowania: E. Junod - J.D. Kaestli, CCAp 1, Turnhout 1983, 527-541; J.E. Spittler, Animals in the Apocryphal Acts of the Apostles, Tübingen 2008, 96-110; E. Plümacher, Paignion und Biberfabel, „Apocrypha” 3 (1992) 69-109, spec. 69-91. Wszystkie te trzy opracowania zostały obficie wykorzystane w niniejszym artykule.

${ }^{5}$ Por. Plinius, Historia naturalis XXIX 61, ed. W.H.S. Jones, London 1963 (Loeb), 322.

${ }^{6}$ Najobszerniejsze omówienie, choć bez podania wszystkich świadectw, znajdujemy w artykule W. Richter, Wanze, w: Pauly-Wissowa, Suppl. XIV, München 1974, 822-825; por. także Thesaurus linguae latinae, III, Lipsiae 1907, 1058.

${ }^{7}$ Por. Aristoteles, Historia animalium V 31, tłum. P. Siwek, w: Arystoteles, Dzieła wszystkie, III, Warszawa 1992, 467.

${ }^{8}$ Por. Varro, Res rusticae I 2, 25, ed. J. Heurgon, Paris 1978, 19.

${ }^{9}$ Plinius, Historia naturalis, zob. wyżej n. 5.

${ }^{10}$ Por. Isidorus, Etymologiarum XII 5, 17, 2, PL 82, 450A.

${ }^{11}$ Pełniejszy ich zestaw, por. W. Richter, art. cyt., kol. 823. 
ranego dosłownie przez pluskwy ${ }^{12}$. Tenże sam element pojawia się także $\mathrm{w}$ innych jego komediach, jak np. w Żabach i Plutosie ${ }^{13}$, podobnie jak w komediach Liwiusza Andronika ${ }^{14}$ i Plauta ${ }^{15}$, u Parmeniona cytowanego w Antologii Palatyńskiej ${ }^{16} \mathrm{i}$ u św. Hieronima ${ }^{17}$. Jeszcze w VII wieku skarży się na pluskwy, które mu spać nie dadzą, niemniej żarliwie niż arystofanesowski Strepsjades, świętobliwy biskup Eugeniusz z Toledo ${ }^{18}$. Na tę plagę starożytni szukali lekarstwa, stąd też pisarze starożytni podawali różnorodne środki przeciw pluskwom, które Warron każe wybijać ${ }^{19}$. Ze względu na uciążliwość pluskiew stają się one przezwiskiem: nazywa się nim rajfurów ${ }^{20}$, a także... krytyków literackich ${ }^{21}$. Julian z Eklanum, przeciwnik św. Augustyna w czasie sporów pelagiańskich, opinię biskupa Hippony porównuje do pluskwy ${ }^{22}$.

Pluskwy były też symbolem biedy. Posiadać jedną pluskwę znaczyło cierpieć skrajną biedę ${ }^{23}$. Wedle Sennika Artemidora, pluskwa pojawiająca się we śnie oznaczała nieszczęścia wśród domowników, które dotyczą szczególnie kobiet²4.

${ }^{12}$ Por. Aristophanes, Nubes 709-715, tłum. J. Tyszkowska-Ławińska, w: Arystofanes, Komedie, I, Warszawa, 211: „Strepsjades: «Ginę nieszczęsny, bo z tego siennika// wyłażą, gryzą mnie... Koryntyjczycy,// zżerają boki// wypiją duszę ciągną za jaja// przeorują tyłek,// zabijają mnie!»". Gra słów w j. greckim: Koryntyjczycy i koris (pluskwa), por. wyżej; tamże, ww. 725, s. 212: „Strepsjades: «Czy po tych pluskwach coś ze mnie zostanie»?".

${ }_{13}$ Por. Ranae 112-116, thum. J. Tyszkowska-Ławińska, II, Warszawa 2003, 255; „Dionizos: «Powiedz mi także o portach, piekarniach// gdzie są burdele, karczmy dróg rozstaje,// źródła, zajazdy, miasta i gospody, // gdzie najmniej pluskiew»”; Plutos 540-541, tłum. J. Tyszkowska-Ławińska, tamże, s. 438: „Chremylos: «A prócz tego wszystkiego zamiast płaszcza masz łachman; do spania zaś masz zamiast łożka// legowisko ze słomy, a nim roje pluskiew, które zasnąć nie dają»”.

${ }^{14}$ Por. Livius Andronicus, Gladiolus, frg. 1, w: Remains of Old Latin, II, ed. E.H. Warminton, London 1961 (Loeb).

${ }^{15}$ Por. Plautus, Curculio 500, ed. A. Ernout, Paris 1961, 92.

${ }^{16}$ Por. Parmenion, Anthologia Palatina IX 113, ed. P. Waltz, Paris 1957, 45.

${ }^{17}$ Por. Hieronymus, Tractatus in Ps 1, CCL 78, 9.

${ }^{18}$ Por. Eugenius Toletanus, Versus de aestate (101) 22-24, PL 87, 368 lub MGHaa XIV 270, thum. M. Bednarz w: A. Bober, Antologia patrystyczna, Kraków 1965, 371: „Mucha i czarny karaluch się sroży // Cuchnąca pluskwa i komar krwi chciwy // A pchła już czyha, gdy człek się położy // Och, ledwom żywy! // Wytrać plugastwo to, o dobry Boże! // Oddal udrękę i obdarz spokojem // Niech na sen zdrowy chociaż raz ułożę // To ciało moje".

${ }^{19}$ Por. Varro, Res rusticae I 2, 25, ed. J. Heurgon, Paris 1978, 19.

${ }^{20}$ Por. Plautus, Curculio 500, zob. wyżej n. 15.

${ }^{21}$ Por. Horatius, Satura I 10, 78, tłum. O. Jurewicz: Kwintus Horacjusz Flakkus, Dzieła wszystkie, II, Warszawa 2000, 127.

${ }^{22}$ Por. Augustinus, Contra Julianum IV 55, PL 44, 764-765, thum. J. Sulowski, PSP 19/2, 52: „Opinię moją porównujesz do pluskwy, która za swego życia jest dokuczliwa, a po uduszeniu wydaje przykry zapach".

${ }^{23}$ Por. Catullus, Carmina 23, 2, thum. A. Świderkówna: Katullus, Poezje, BN II 105, Wrocław 1956, 22: „Furiuszu! nie masz skrzyni, niewolnika // Pluskwy, pająka, w piecu ni podpłomyka”; Martialis, Epigrammata XI 32, 1; 56, 6 (o stoiku Chairemonie).

${ }^{24}$ Por. Artemidorus, Onirocriticon 3, 8, ed. A. Giardino, Milano 2006, 444. O tym dziele, por. A. Krawczuk, Sennik Artemidora, Warszawa 1972. 
Pluskwy stały się również przedmiotem dyskusji teologicznych. Już w czasach przedchrześcijańskich postawiono problem celowości istnienia pluskiew i innych dokuczliwych stworzeń, bo przecież natura nie rodzi nic na darmo ${ }^{25}$. Chryzyp w tej dyskusji na temat celowości w naturze, stawia pytanie o sens istnienia pluskiew i odpowiada, że istnieją, aby budzić ludzi, by nie spali za długo $^{26}$, podobnie i Artemidor ${ }^{27}$. Pliniusz podaje szereg możliwości wykorzystania pluskiew, choć stwierdza, że jest to zwierzę najobrzydliwsze ${ }^{28}$. Temat ten podejmują także pisarze chrześcijańscy, traktujący problem celowości w naturze: jeśli bowiem Bóg stworzył wszystko na pożytek człowieka, to czemu stworzył np. pchły i pluskwy ${ }^{29}$ ? Dlaczego było rzeczą konieczną, by Pan Bóg je stworzył ${ }^{30}$. $\mathrm{Na}$ te pytania odpowiada św. Hieronim: istnieją, aby przypominać nam o kruchości naszego ciała ${ }^{31}$.

Innym tematem teologicznym, w którym występowały pluskwy, jest teza manichejczyków, że dusze rozumne mogą być wtrącane w ciała zwierzęce. Tak zatem, ironizuje św. Augustyn w polemice z manichejczykiem Adimantem: mogą oni zabijać rodziców pomiędzy wszami i pchłami ${ }^{32}$. Podane tu teksty wprowadzają nas w kontekst historyczno-ideologiczny naszego opowiadania.

Jeśli zaś chodzi o stronę kompozycji dzieła, to opowiadanie o pluskwach w gospodzie należy więc zaliczyć do oryginalnych opowiadań o zwierzętach, jako że występują tam z zasady zwierzęta nobliwsze niż pogardzane pluskwy, a ponad to epizody o owadach występują na ogół rzadko. Tu natomiast mamy opowiadanie o zwierzętach aż nazbyt prozaicznych - pladze domów i gospód starożytnych, i to właśnie stanowi o oryginalności tego fragmentu.

Oryginalność opowiadania polega także na tym, że mówi o żarcie Apostoła ( $\pi \alpha^{\prime}$ iviov). Takie opowiadania o żartach apostolskich spotykamy wyłącznie w apokryficznych Dziejach Jana, a więc opowiadanie o portrecie Jana, gdzie Apostoł żartuje z Likomedesa, który go sobie powiesił w pokoju ${ }^{33}$, epizod z kuropatwą, który rozśmieszył Jana, czy też z którą bawił się Jan ${ }^{34}$, oraz nasze opowiadanie. Cała ponadto scena jest przedstawiona w stylu kameralnym, co podkreśla pierwsza osoba opowiadania, dobrze harmonizująca $\mathrm{z}$ tonem opowiadania ${ }^{35}$.

\footnotetext{
${ }^{25}$ Por. Chrysippus, Fragmenta, w: Stoicorum Veterum Fragmenta 1140, Milano 2002, 937.

${ }^{26}$ Por. Plutarchus, De stoicorum repugnantiis 1044d-e, ed. A. Casevitz - D. Babut, Paris 2004, 56.

${ }^{27}$ Por. Artemidorus, Onirocriticon 3, 8.

${ }^{28}$ Por. Plinius, Historia naturalis XXIX 61-62, ed. W.H.S. Jones, London 1963, 322 (Loeb).

${ }^{29}$ Por. Hieronymus, In Psalmum 91, CCL 78, 136; In Joël 2, 22, PL 25, 973.

${ }^{30}$ Por. Arnobius, Adversus nationes II 47, PL 5, 867-868.

${ }^{31}$ Por. Hieronymus, In Joël 2, 22, PL 25, 973.

${ }^{32}$ Por. Augustinus, Contra Adimantum 12, 2, CSEL 25, 139, thum. J. Sulowski, PSP 54, 171: „Nie powiem, że mógł nawet zabić swoich rodziców pomiędzy wszami i pchłami”; De moribus Ecclesiae catholicae et de moribus Manichaeorum II 17, 63, PL 32, 1372.

${ }^{33}$ Por. Acta Joannis 10, CCAp 1, 177, Apokryfy Nowego Testamentu II/1, 298-299.

${ }^{34}$ Por. niżej Dodatek.

${ }^{35}$ Por. E. Plümacher, Paignion und Biberfabel, „Apocrypha” 3 (1992) 69-109, spec. 69-91.
} 
Posiadamy kilka starożytnych opowiadań o zwierzętach, które podejmują motywy podobne do tych, występujących w naszym opowiadaniu, ponieważ mówią o stworzeniach posłusznych człowiekowi. Gdy Herkulesowi zmęczonemu podróżą przeszkadzały świerszcze podczas odpoczynku koło Rhegion, poprosił bogów o pomoc, a ci usunęli je definitywnie z tej okolicy ${ }^{36}$. Podobnie, gdy Perseusz, zmęczony po walce z Gorgoną, nie mógł usnąć z powodu odgłosów żab na wyspie Seriphos na Cykladach, Zeus na jego prośbę zmusił je do wiecznego milczenia ${ }^{37}$. Te dwa opowiadania sa jednak typowo etiologiczne (tłumaczące pewną specyfikę tych dwóch miejsc), a bohaterowie zwracają się do bogów o pomoc, której oni im udzielają, tu natomiast Jan czyni to własną mocą; jest to ponadto opowiadanie o Janie, a nie o sytuacji pewnego miejsca. Niemniej jednak mamy tu do czynienia z motywem zwierząt przeszkadzających we śnie i przez niego (z pomocą bogów) wyciszonych.

Inne opowiadanie o posłusznych owadach, to te o muchach, które opuszczały Olimpię na czas igrzysk samowolnie lub stało się to na skutek prośby Herkulesa ${ }^{38}$, podobnie rzecz się miała $\mathrm{z}$ muchami w święto Apollina w Actium ${ }^{39}$. Ale obydwa te cuda powtarzały się wielokrotnie. Te opowiadania łączą się z wnioskami moralnymi: podobnie jak muchy opuszczają Olimpię, tak muszą je opuścić również kobiety, ale muchy czyniły to dobrowolnie. Analogicznie rzecz się ma z opowiadaniami z kręgu neopitagorejczyków Pitagoras wywiera wpływ na zwierzęta i odwołuje się do ich uczućc ${ }^{40}$, podobnie jak czyni to Jan w naszym opowiadaniu, choć w tych opowiadaniach jest mowa o „nawróceniach moralnych” zwierząt, którego to elementu brak w naszym opowiadaniu.

Opowiadanie o pluskwach zawiera chrześcijański, grecki termin $\eta \sigma v \chi \alpha ́ \zeta \omega$, który ma długą tradycję teologiczno-ascetyczną w literaturze chrześcijań-

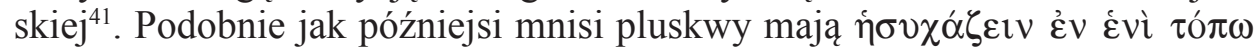
- a więc przebywać wyciszone w jednym miejscu! Nie można się oprzeć wrażeniu, że mamy tu do czynienia z elementem kpiny, kiedy do pogardzanych pluskiew odnosi się termin stanowiący określenie tego, co następnie się stało określeniem szczytu ascezy monastycznej. Rodzi się jednak pytanie, jakie

\footnotetext{
${ }^{36}$ Por. Diodorus Siculus, Bibliotheca historica IV 22, ed. C.G. Goldfather, London 1953, 414 (Loeb).

${ }^{37}$ Por. Aelianus, De natura animalium 3, 37, ed. F. Maspero, I, Milano 1998, $201 \mathrm{nn}$.

${ }^{38}$ Por. tamże 5, 17, ed. F. Maspero, I, s. 299; Pausanias, Graeciae descriptio V 14, ed. H.A. Ormerod, 2, London 1960, 456 (Loeb).

${ }^{39}$ Por. Aelianus, De natura animalium 11, 8, ed. F. Maspero, II, s. 647.

${ }^{40}$ Por. Porphyrius, Vita Pythagorae 23-25, thum. J. Gajda-Krynicka, Wrocław 1993, 11; Jamblichus, Vita Pythagorae 13, 60-62.

${ }^{41}$ Por. S. Horuj, Hysychasm. An annotated bibliography, Moscow 2004 (po rosyjsku). Zwrot ten oznacza ,spokój w życiu religijnym, prowadzący do modlitwy”, zob. G.W.H. Lampe, A Patristic Greek Lexicon, Oxford 1961, 608.
} 
znaczenie miało to słowo w II wieku? Jak bowiem z tego widać, opowiadanie nasze jest bardzo dobrze osadzone $w$ realiach i klimacie tamtej epoki.

Mamy do czynienia z opowiadaniem o żarcie Apostoła lub żartobliwym opowiadaniem o Apostole, a ponadto zawierające elementy żartobliwe, jak np. czcigodny Apostoł przemawiający do pluskiew ${ }^{42}$, a także ze względu na aluzje i na podteksty. Czy jednak pochodzą one od autora dzieła czy też od kopistów, nie wiemy. Jest to więc wypadek szczególny pośród licznych opowiadań chrześcijańskich o zwierzętach, na ogół poważnych i namaszczonych, i o treści teologicznej, choć często komicznych w swym patosie, jak opowiadanie o psie wspomagającym św. Piotra ${ }^{43}$, lub cudzie ze śledziem w tymże apokryfie ${ }^{44}$. Tu natomiast mamy po prostu żart. Należy jednak zwrócić uwagę na fakt, że poważni mnisi pustyni dopuszczali pewną formę żartu, jak w sławnym apoftegmacie św. Antoniego o tym, że nie można ciągle trzymać łuku napiętego, bo pęknie: raz po raz należy go poluzować; te słowa przypisał Jan Kasjan właśnie św. Janowi idąc za tradycją apokryfów Janowych.

Jeśli chodzi o stronę formalną, to wyjątkowym wypadkiem w apokryfach jest zastosowanie w tym opowiadaniu formy ,ja”: autor pojawia się w nim jako świadek naoczny. Podobnie oryginalnym jest pytanie końcowe, jednak nie najlepiej pasujące do całości fragmentu. Jest to, dodajmy, opowiadanie mało spektakularne i epizodyczne.

Autorzy piszący o tym epizodzie wyszukują paralele dla poszczególnych elementów tego opowiadania, które niewątpliwe pozwalają wyjaśnić niektóre jego elementy. Ale ostatecznie stwierdzić musimy, że nie mamy dla tego tekstu wzoru: jest to tekst oryginalny, zarówno ze względu na wybrane zwierzęta, jak i na jego treść.

Czy mamy tu do czynienia z opowiadaniem organicznie związanym z tekstem Dziejów Jana? Niewątpliwie mamy szereg elementów wiążących go z treścią, niemniej jednak trudno się oprzeć uczuciu obcości tego fragmentu w całości dzieła. Czy pochodzi on z uchrystianizowanego opowiadania, czy zawiera element tradycji Janowych, będących poza Dziejami, jak np. opowiadanie o Janie zawarte w Quis dives salvetur Klemensa Aleksandryjskiego ${ }^{45}$, nie wiemy.

Jeśli zaś stawiamy pytanie, dlaczego właśnie tak podłe zwierzęta, jak pluskwy, wybrał autor opowiadania, to wydaje się, że po pierwsze autor wyszedł

${ }^{42} \mathrm{~W}$ apokryfach spotykamy dość często motyw rozmowy zwierząt z człowiekiem. O tym porozumieniu człowieka ze zwierzęciem pisze także Porfiriusz w De abstinentia 3, 4 (ed. J. Bouffartigue - M. Pwetillon, Paris 1979, 156n).

${ }^{43}$ Por. Acta Petri 9-10, thum. w: Apokryfy Nowego Testamentu, II/1, 496-497.

${ }^{44}$ Por. tamże 13, Apokryfy Nowego Testamentu, II/1, 500.

${ }^{45}$ Por. Clemens Alexandrinus, Quis dives salvetur 42, GCS 17, 190, thum. J. Czuj : Który człowiek bogaty może być zbawiony, oprac. J. Naumowicz, MBOK 2, Kraków 1995, 112-117. 
w opowiadaniu od typowej rzeczywistości, z którą spotykali się w gospodach podróżujący, tak jak Jan. Dlaczego więc Apostoł w swych podróżach, nocując w gospodach, nie miał doznać utrapień ze strony pluskiew? - element realizmu wkroczył do atmosfery cudowności utworu o Apostole Janie. Dodatkowym powodem mógł być fakt, że starożytny dowcipniś wykorzystał gry słów i nadał opowiadaniu dość specyficzny dwuznaczny podtekst i dwuznaczną interpretację treści.

Nie wiem, czy Czytelnicy tego tekstu będą umieli się z niego śmiać, jak śmiali się uczniowie św. Jana. Być może, kogoś może zgorszyć opracowywanie żartu św. Jana Apostoła, poważnie przemawiającego do pluskiew, i naukowe omówienie ich roli w starożytności chrześcijańskiej. Pluskwy jednak, czy chcemy czy nie chcemy, stanowiły element życia zwykłych chrześcijan, i z pewnością niejednokrotnie pogryzły świętych Doktorów Kościoła, m.in. św. Augustyna i Hieronima, oraz wielu innych, w ich licznych podróżach, stąd nawiązują do nich oni i inni Ojcowie Kościoła, stąd też odnośniki do ich dzieł w niniejszym tekście.

A gorszącym się z żartów, nawet u Ojców Kościoła, warto zacytować słowa Jana Kasjana skierowane do mnichów, a włożone w usta bohatera niniejszego opowiadania, św. Jana Apostoła:

„«Niechaj więc, młodzieńcze», rzekł błogosławiony Jan, «Nie gorszy cię także ten lekki i krótki odpoczynek naszego umysłu; bo gdybyśmy czasem nie złagodzili i nie zluźnili jego napięcia jakimś wytchnieniem [mowa o naciągniętym łuku], to musiałby, osłabiony nieustannym natężeniem, odmówić posłuszeństwa sile ducha właśnie wtedy, gdy konieczność wymaga jego sprawności»" ${ }^{\natural 6}$.

${ }^{46}$ Joannes Cassianus, Collationes 24, 21, CSEL 13, 697-698, thum. L. Wrzoł, POK 7, 450-451, cytowane w: Apokryfy Nowego Testamentu, II/1, 335. To opowiadanie wzięte jest z apoftegmatów Ojców Pustyni, por. Gerontikon: Antoni 13 (13), ŹM 4, 139. 


\section{DODATEK}

\section{Żart św. Jana - Epizod z kuropatwą}

\section{a. Tekst grecki (Dzieje Jana 56-57).}

56. „Pewnego dnia, kiedy Jan sobie siedział, przyleciała kuropatwa i zaczęła się przed nim tarzać w prochu, a Jan patrzał na nią z podziwem. Przyszedł tam pewien kapłan, który był jego słuchaczem, podszedł do Jana, ujrzał kuropatwę tarzającą się w prochu przed nim i zgorszył się, mówiąc sam do siebie: «Tak znakomity człowiek i w takim wieku, bawi się z kuropatwą, tarzającą się w prochu». Jan jednak poznał jego myśli i rzekł do niego: «Byłoby lepiej dla ciebie, dziecko, gdybyś przyglądał się kuropatwie tarzającej się w prochu, zamiast brudzić się myślami szpetnymi i nieczystymi. Ten bowiem, który zna nawrócenia i pokutę wszystkich, sprowadził cię tu dla obejrzenia widowiska, a mianowicie, że ja muszę oglądać kuropatwę tarzającą się w prochu - ta bowiem kuropatwa przedstawia twoją duszę».

57. Gdy więc kapłan to usłyszał i zobaczył, że nic się nie mogło ukryć, ale wszystko, co było w jego sercu powiedział mu Jan - Apostoł Chrystusa, padł twarzą na ziemię i zawołał: «Teraz wiem, że w tobie zamieszkuje Bóg, o błogosławiony Janie! Błogosławiony jest również ten, kto w sobie nie kusił Boga. Bowiem próbując ciebie próbuje również tego, kogo próbować nie można». Prosił on więc, by Jan modlił się za niego. Jan zaś go pouczył i podał mu zasady, a następnie odesłał go do jego domu, a on chwalił Boga za wszystko"47.

\section{b. Tekst laciński (Jan Kasjan, Rozmowy 24, 21, 1-3).}

1. „Niesie podanie, że pewnego razu błogosławiony Apostoł Jan głaskał pieszczotliwie kuropatwę, gdy naraz ujrzał jakiegoś filozofa zbliżającego się doń w stroju myśliwskim. Zdziwił się filozof, że mąż tak wielkiej sławy i poważania zniża się do tak błahych i niskich rozrywek. «Tyś to - rzekł do niego - tyś to ten Jan, którego wielka i rozgłośna sława zwabiła także i mnie, iż zacząłem gorąco pragnąc poznania ciebie? Po cóż więc bawisz się tak marną rozrywką?».

2. Rzekł do niego błogosławiony Jan: «Cóż to jest, co trzymasz w ręce»? «Łuk» - odpowiedział. «A dlaczego nie nosisz go zawsze i wszędzie napiętym»? «Nie byłoby to dobrze - odpowiedział - bo osłabłaby i zanikła siła jego

\footnotetext{
${ }^{47}$ Acta Apostolorum Apocrypha, ed. R. Lipsius - M. Bonnet, 2/1, 178-179; por. CCAp 1, 145-156.
} 
napięcia zluźniona przez ciągłe skrzywienie; a gdyby zaszła potrzeba silniejszych strzałów do jakiejś zwierzyny, to ostrzejszy cios stałby się niemożliwy, bo przez ciągłe nadmierne nagięcie już by przedtem utracił swą siłę».

3. «Niechaj więc, młodzieńcze», rzekł błogosławiony Jan, «nie gorszy cię także ten lekki i krótki odpoczynek naszego umysłu; bo gdybyśmy czasem nie złagodzili i nie zluźnili jego napięcia jakimś wytchnieniem, to musiałby, osłabiony nieustannym natężeniem, odmówić posłuszeństwa sile ducha właśnie wtedy, gdy konieczność wymaga jej sprawności»" ${ }^{\text {"48 }}$.

\title{
LES PUNAISES OBÉISSANTS À S. JEAN L'APÔTRE \\ DANS LES ACTES DE JEAN
}

\begin{abstract}
(Résumé)
Dans les Actes apocryphes de Jean (chap. 64), du II/III ${ }^{\mathrm{e}}$ s., on trouve un épisode avec les punaises: l'Apôtre commande aux insectes de ne pas inquiéter ses élèves. Cet épisode appartiennt au grupe de récits sur les animaux, populaires dans l'antiquité soit païenne soit chrétienne; ici nous avons affaire à un typique récit sur les animaux obéissants. Ce qui caractérise ce récit est le fait que l'auteur le présente à la première personne et qu'il prend comme objet les punaises - insectes détestés et méprisés chez les auteurs anciens. Dans l'article on analyse les mentions sur les punaises chez les auteurs anciens et les récits sur les animaux obéissants. Enfin ce récit appartiens à un groupe de récits-plaisanteries qu'on rencontre dans les Actes de Jean (l'épisode avec le perdrix, l'épisode avec le portrait de Jean).
\end{abstract}

${ }^{48}$ Por. wyżej n. 46. 